\title{
Anthropometry and lifestyle of children and adolescent in inland of northeastern Brazil
}

Open acess

${ }^{1}$ Laboratório de Patologia Investigativa, Hospital Universitário, UFS -

Universidade Federal de Sergipe,

Aracaju, Sergipe, Brasil.

${ }^{2}$ Secretaria Municipal de Saúde, Frei Paulo, Sergipe, Brasil.

Corresponding author:

diegomouratanajura@gmail.com

Manuscript received: 20 January 2017 Manuscript accepted: 02 May 2017

Version of record online: 06 September 2017
Bianca Vanessa dos Santos Ribeiro', Rafaela Gois de Mendonça ${ }^{1}$, Laís Lima de Oliveira ${ }^{1}$, Gêniton Santos Lima², Paulo Ricardo Saquete Martins-Filho ${ }^{1}$, Nathale Prates Ribeiro Moura', Diego Moura Tanajura $^{1}$

\section{Abstract:}

Introduction: Brazil is going through a nutritional transition, which is observed decrease in malnutrition and increased excess weight.

Objetive: To evaluate the nutritional status and lifestyle of school children and adolescents from 4 to 17 years old resident in the interior of the Brazilian Northeast.

Methods: This is a longitudinal study performed in two stages. The first stage took place during the School Health Program and anthropometric data were collected from 975 schoolchildren. In the second stage, it was used a questionnaire to assess lifestyle and diet. Participants were classified into "not overweight" and "overweight". The significant level for the statistical tests was set at $5 \%$.

Results: In the first stage, less than $2 \%$ of students had low height for age. The prevalence of overweight and malnutrition was $22.15 \%$ and $5.23 \%$, respectively. Of the 134 participants of the second stage, $47.76 \%$ were not overweight and $52.24 \%$ overweight. Regarding the lifestyle, the not overweight group had a higher percentage of insufficiently active members $(p=0.017)$ and a lower intake of vegetables and salads $(p=0.015)$.

Conclusion: The results revealed low short stature in the population studied and overweight was more prevalent than malnutrition. Children and adolescents had sedentary habits that associated with inappropriate dietary practices favor the occurrence of overweight.

Keywords: overweight, obesity, child, adolescent, food consumption, life style 


\section{INTRODUCTION}

The World Health Organization (WHO) considers obesity as one of the greatest problems of public health in the world, and estimates that in 2025 about 2.3 billion adults will be with overweight and more than 700 million, obese. In the past, excess weight was considered a problem of developed countries; now, it is also on the rise in underdeveloped and developing countries, historically known by the scenario of hunger and malnutrition. In the year 2013, 42 million children under 5 years old had excess weight; these numbers may reach 75 million if there is no intervention ${ }^{1,2}$.

In Brazil, developing country which is in nutritional transition, obesity is growing rapidly. Data indicate that $52.5 \%$ of the Brazilian population is above the ideal weight, and of these, $17.9 \%$ is obese $^{3}$. In the northeast region the rates of overweight in the pediatric population with ages between 5 to 9 years and 10 to 19 years are of $28.15 \%$ and $16.6 \%$, respectively. Compared to the southeast region, the values found are smaller, however they already demonstrate the increasing prevalence of excess weight characteristic of nutritional transition ${ }^{4}$.

With the increasing prevalence of obesity in children and adolescents, their complications have also become more frequent. Diseases such as diabetes mellitus type 2, cardiovascular diseases, osteoarticular diseases and respiratory diseases and

\section{METHODS}

This was a longitudinal study conducted in Frei Paulo, a city located in the interior of the state of Sergipe. The data of the first part of the study were collected by the research team in conjunction with the team of professionals of the Family Health Strategy (FHS), during the action of the Health at School Program (HSP) in the year 2014. Children and adolescents were included in the study between 4 and 17 years old enrolled in public schools (state and municipal) of the urban area, participants of the HSP and who were present on the day of collection. The initial sample was composed of 997 schoolchildren, meanwhile, 22 were excluded from the study because they have age greater than or equal to 18 years. Thus, the final sample was comprised of 975 students.

For anthropometric assessment data on weight and height were collected. The body weight was measured in $\mathrm{kg}$ through a scale with a precision of $100 \mathrm{~g}$, with the school children wearing light clothes and barefoot and juxtaposed; height was measured in centimeters $(\mathrm{cm})$, in a wall stadiometer, with a precision of $1 \mathrm{~mm}$.

For nutritional classification, we used the height/age index, in order to diagnose growth deficit, and the index body mass/age (BMI/age) for excess weight, in accordance with the values proposed by $\mathrm{WHO}^{11}$. Children and adolescents with the height percentile for age $<3$ were classified as low stature, psychosocial aspects that until a short time ago were rare in children and adolescents, today are more common $^{5-7}$.

The obesity results from an energy imbalance in that the amount of energy consumed is greater than the quantity used. The determinant factors of this imbalance may have a genetic, metabolic, environmental and behavioral origin. The great majority of cases of obesity is caused by exogenous factors (socioenvironmental) - around 95\% - while the endogenous factors (neuroendocrine effects or genetic) have participation in a minority of patients - about 5\%, which demonstrates the importance of lifestyle in the genesis of obesity ${ }^{8,9}$.

For being a disease whose installation takes place so increasingly earlier, combating obesity requires interventions mainly directed to children and adolescents. Data demonstrate that an obese child in the first six months of life has 2.3 times more chances of becoming an obese adult, while in obese adolescent this probability is 6.5 times $^{8}$. The political proposals consider more effective the health interventions conducted in schools, given that children and adolescents spend more time in this location than in any other environment outside home $^{10}$. Thus, the objective of this study was to evaluate the anthropometric data and the life style of children and adolescents from 4 to 17 years.

and those with percentile $\geq 3$ were classified with adequate stature. As to the BMI, the cutoff points used were: underweight for percentile $<3$; weight appropriate for between 3 and 85 percentiles; excess weight to $>85$ percentile, including overweight and severe obesity.

Once this first stage of the study used secondary data obtained from an official program of the government, it was requested to the Municipal Secretariat of Health the permission for the use of data and dissemination of the results obtained.

In the second step of the study, which was performed four to six months after the first step, the school children and their parents were invited to participate of a cycle of lectures on obesity and its complications, healthy food and the practice of physical activity. Before the beginning of the lectures, it was explained the objective of the study and all parents present consented with the participation of their children and signed a Free and Informed Consent Term (FICT).

This way, 144 schoolchildren were evaluated as to the life style and food consumption. Then the students or responsible (in case they were under 10 years) answered a questionnaire containing questions about the practice of physical activity and sedentary lifestyle, the frequency of consumption of vegetables, salads, fresh fruit and candies (drops, chocolate, biscuits and soft drinks). Ten 
questionnaires were excluded by mistakes filling. Some participants also did not answer some questions, however, this was not sufficient to nullify the use of their questionnaires. The students were divided into two groups: "without excess weight" (low weight + normal weight) and with "excess weight" (overweight + obesity).

As a method of analysis of the level of physical activity practiced by students, these were classified as active when practiced 300 minutes or more of moderate to vigorous physical activity per week, and as insufficiently active when practiced less than 300 minutes of physical activity, according to the Dias and collaborators ${ }^{12}$.

In the evaluation of sedentary behavior (hours per day watching $\mathrm{TV}$, using the computer or playing video game), the people responsible for them or the students themselves answered an objectice question: "How long does student spend watching TV, playing video game or using the computer per day? (number of hours of all activities together)." For analysis, it was considered as sedentary behavior the student that spends more than two hours in front of the TV screen, video game or computer per day ${ }^{13}$.

\section{RESULTS}

Out of the 975 students who attended the first stage of the study, $47.8 \%$ (466) was male and 52.2\% (509) was female. The girls presented significantly
To evaluate the difference of the variables between boys and girls it was used the Mann Whitney test. The software BioEstat $(5.3$ was used for these analyzes. In the assessment of nutritional status, it was used the software AnthroPlus (for children/adolescents 5 to 17 years) and Anthro (for children aged 4 years) (WHO AnthroPlus/Anthro for personal computers: software for assessing growth of the children and adolescents' world. Genebra, Switzerland) and the cutoff points defined for the indices height/age and $\mathrm{BMI} /$ age by $\mathrm{WHO}^{11}$.

In the analysis of the life style of children and adolescents, it was adopted Fisher exact test to evaluate the differences between the students "without overweight" and "overweight". The data collected were double entered with the objective of improving their reliability, and analyzed on EpiInfo $\AA$ release ${ }^{7}$.

The statistical tests were applied with a confidence interval of $95 \%$. The study was approved by the Research Ethics Committee of the University Hospital of Aracaju/Federal University of Sergipe (CAEE Number 37644114.2.0000.5546).

higher averages for age, body weight and BMI than for boys $(p<0.05)$. The mean height was similar between the genders (Table 1). Around 2.0\% of

Table 1. Characteristics of the population of students according to gender. Frei Paulo, SE, Brazil, 2014.

\begin{tabular}{lccc}
\hline Variables & \multicolumn{1}{c}{ Average \pm} & standard deviation & $\mathbf{p}$ \\
\hline & Boys $(\mathrm{n}=466)$ & Girls $(\mathrm{n}=509)$ & \\
Age (years) & $11.04 \pm 3.52$ & $11.51 \pm 3.54$ & 0.0413 \\
Height $(\mathrm{cm})$ & $148.0 \pm 20$ & $147.8 \pm 18$ & 0.6496 \\
Body weight $(\mathrm{Kg})$ & $41.95 \pm 16.73$ & $43.63 \pm 15.89$ & 0.0479 \\
BMl $(\mathrm{kg} / \mathrm{m} 2)$ & $18.32 \pm 3.6$ & $19.26 \pm 4.22$ & 0.0003 \\
\hline
\end{tabular}

Note: The Mann Whitney test was used to evaluate the differences between boys and girls. A value of $p<0.05$ was considered significant.

children and adolescents presented low stature for age (data not shown). As to nutritional status, $22.15 \%$ of the schoolchildren were with overweight, including obesity, and $5.23 \%$ were underweight (Figure 1A). According to the stratification by gender, malnutrition was more prevalent in boys $(6.22 \%)$ than in girls $(4.32 \%)$, although not significantly (Figure 1B).

In the second step of the study, in which was assessed the life style and the feeding practice, the final sample was composed of 134 schoolchildren. Out of these, $47.76 \%$ (64) were classified without excess weight and $52.24 \%$ (70) with excess weight. Although there were no differences between the groups regarding the practice of physical activity (Figure 2A) and sedentary behavior (Figure 2C), the school children group classified without excess weight presented an insufficiently active behavior compared with the school children with excess weight $(p=0.017)$ (Figure 2B).

At the item food consumption, a higher percentage of schoolchildren without excess weight did not consume vegetables and salads every day, compared with the school children with excess weight $(p=0.015)$ (Figure 2D). In the case of fruit consumption, although the percentage of schoolchildren who did not consume it to be higher in the group without excess weight, this difference was not significant (Figure 2E). With respect to sweet consumption, this was similar in both groups (Figure 2F). 


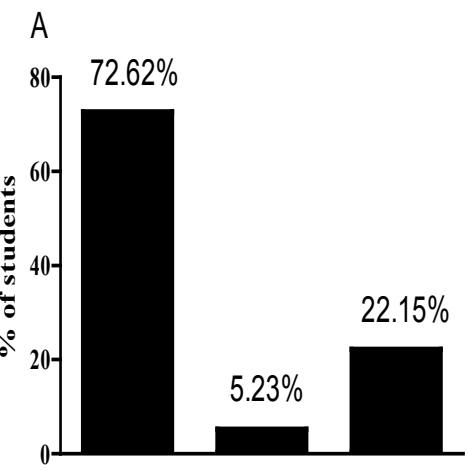

Eutrophic Underweight Overweight

\section{B}

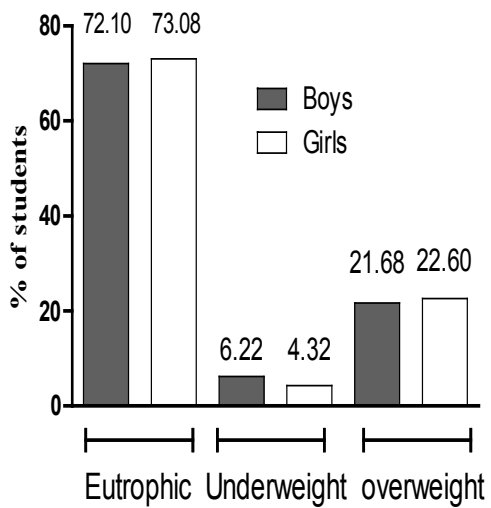

Figure 1. Nutritional status of schoolchildren aged 4 to 17 years of public schools. Frei Paulo, SE, Brazil, 2014. (A) General nutritional status of schoolchildren. (B) The nutritional status of schoolchildren stratified by gender. The values are presented as percent of schoolchildren $(n=975)$.

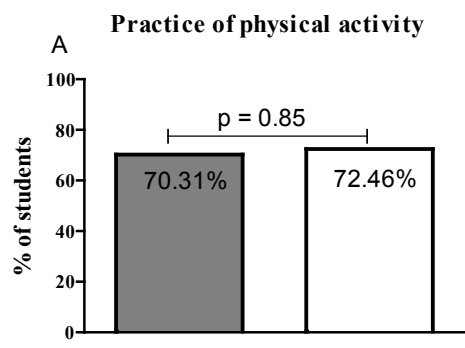

Not consume vegetables daily

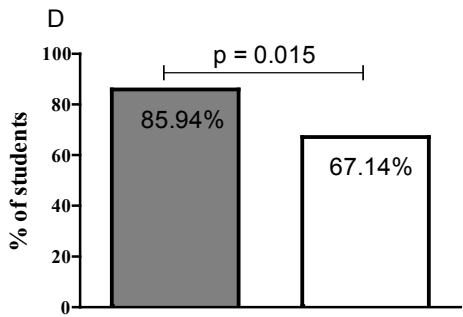

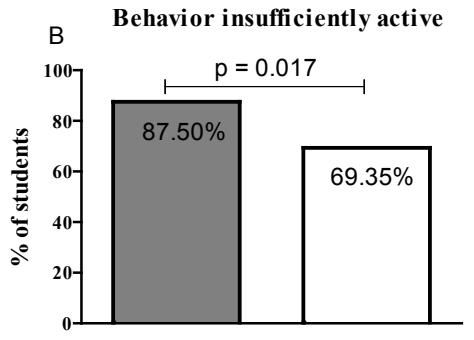
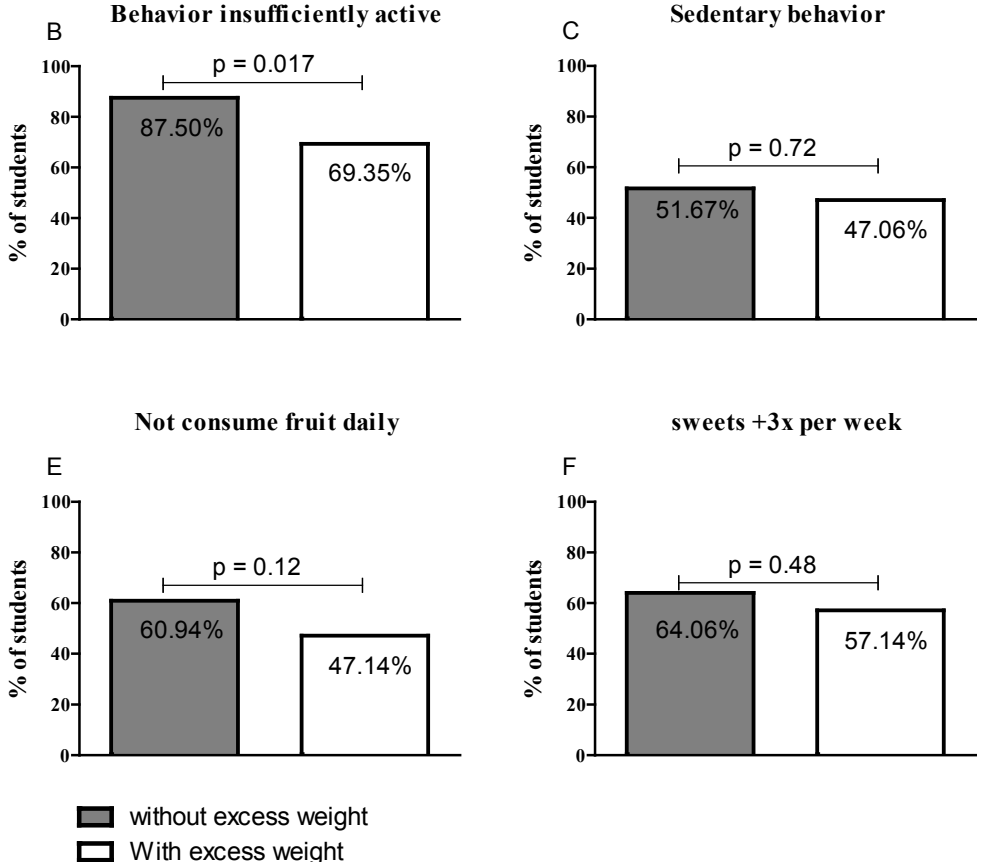

Figure 2: Evaluation of the style of life of the schoolchildren aged 4 to 17 years of public schools. Frei Paulo, SE, Brazil, 2014. (A) Assessment of the practice of physical activity $(n=133)$. (B) Assessment of the behavior insufficiently active ( $n$ =126). (C) Evaluation of sedentary behavior $(n=128)$. (D) The percentage of schoolchildren who do not consume vegetables daily $(n=134)$. (E) Percentage of schoolchildren who do not consume fruit daily $(n=134)$. $(F)$ The percentage of schoolchildren who consume sweets more than three times per week $(n=134)$. The Fisher exact test was used to assess differences between eutrophic and overweight schoolchildren.

\section{DISCUSSION}

The health policies consider the school environment as ideal for promotion, prevention and health education, since it is a reference place for children and adolescents, where they acquire sociocultural behaviors. Within this context, it is developed the HSP, inserted in the school environment and able to reach beyond the limits of the same, through their health interventions. HSP was established in 2007, but only in 2013 has become universal and expanded to daycare centers and pre-schools. The basis of this program is to link the public networks of health and education ${ }^{14}$.

In conjunction with the actions of the HSP, it was carried out the first step of this study, which assessed the nutritional status of schoolchildren in Frei PauloSE. With relation to the stature deficit, only $1.95 \%$ of the schoolchildren exhibited low stature for their 
age, demonstrating that the children and adolescents' growth is appropriate and consistent with the reference of $\mathrm{WHO}^{15}$. In a similar study, which used data from the HSP of Maribondo city-AL, stature deficit was $9.0 \%{ }^{16}$. In Pernambuco state, the survey conducted to evaluate the short stature indicated a decrease of this problem which fell from $16.9 \%$ in 1997 to $9.6 \%$ in $2006^{17}$. Soon, it is observed that Frei Paulo presented a height deficit approximately five times lower compared to the studies described above.

In the assessment of nutritional status, 22,15\% of the schoolchildren were with excess weight. Similar results were observed in the city of Sorocaba-SP $(22.1 \%)^{18}$ and in the interior of Pernambuco $(17.8 \%)^{19}$. In the interior of Alagoas, this rate ranged from 23.2 to $35.5 \%$ depending on the age range ${ }^{16}$. Anthropometric data in the Brazilian regions indicate that the Northeast is undergoing a process of nutritional transition, in which there is a decrease of malnutrition and an increase of excess weight. The malnutrition in this region reaches percentage of around $5 \%$, and the rate of excess weight varies between 16.6 to $28.15 \%$. The most developed regions of Brazil presented lower rates of malnutrition, which vary from 2 to $3 \%$; on the other hand, they show rates of excessive weight higher, which vary between 24.6 to $35.9 \%$ and 22.8 to $38.8 \%$ in the South and Southeast regions, respectively (approximate data) ${ }^{4}$. With relation to malnutrition in the city of Frei Paulo, this presented rate similar to that found in the Northeast Region.

Some developed countries have observed a stabilisation in the rates of excess weight in children and adolescents. However, it is worrying that the growing number of severe obesity in these groups. In the United States severe obesity affects 4 to $6 \%$ of young people. The children with nutritional diagnosis of severe obesity present a high risk of developing diabetes type 2 and cardiovascular problems in early ages, including hypertension and dyslipidemia, even in comparison with the obese and overweight patients ${ }^{20}$. In Frei Paulo, the percentage of school children and adolescents diagnosed with severe obesity was $1.5 \%$. In the interior of São Paulo state, a study carried out with students aged between 6 and 17 years observed similar data for severe obesity $(1.74 \%)^{21}$.

The rates of eutrophy, malnutrition and overweight in Frei Paulo were similar between boys and girls. The excess of weight between the genders in Brazil showed figures close to those of the present study $-22.1 \%$ and $24.3 \%$ in boys and girls, respectively ${ }^{22}$. However, a study performed in the capital of the state - Aracaju, prevalence of excess weight was less in both genders- $16.5 \%$ and $18.1 \%$ in boys and girls, respectively ${ }^{23}$. The differences in the prevalence of excess weight observed in Frei Paulo and Aracaju can be explained by the target population of the study, that already at work of Polderman and collaborators $^{23}$ participated only students from 12 to 17 years.

In the second step of the study it was evaluated the students' lifestyle who participated of the research. The majority of the members of the two groups evaluated - without excess weight and excess weight, reported physical activity practice. However, $87.5 \%$ of the students classified as without excess weight had insufficiently active behavior, and this was significantly greater than in the group with excess weight $(69.35 \%)$ ( $p<0.017)$. With relation to the sedentary behavior (evaluation of screen time), the rates were similar between the two groups. These results were different from other studies. In the work of William and collaborators ${ }^{24}$, for example, students classified with excess weight had 1.8 times more chance of being insufficiently active. Dias and collaborators $^{12}$ also observed an association between excess weight in adolescence and insufficiently active behavior. On the other hand, Aires and collaborators ${ }^{25}$ found no association between excess weight and inactive behavior and Lucena and collaborators ${ }^{26}$ also found no association with sedentary behavior. The differences of the results presented by the studies may be explained by methodological differences, as described in a systematic review that evaluated the relationship between sedentary behavior and excess weight ${ }^{27}$.

In the evaluation of feeding practice, inadequate habits predominated, mainly in the group without excess weight. It was observed that $86 \%$ of student in the group without excess weight did not consume vegetables and salads every day, $61 \%$ did not consume fruit every day and 64\% consumed sweets (sweets, chocolates, biscuits and soft drinks) more than three times a week. Previous study performed in Aracaju-Se revealed similar findings, to the extent that evidenced the insufficient consumption of fruits and vegetables among adolescents. Moreover, the insufficiently active behavior was related to the inadequate consumption of fruits and vegetables ${ }^{28}$, as observed in this study. Research performed in two cities of Rio Grande do Sul reported similar consumption of soft drinks between obese and non-obese ${ }^{29}$. The results found by Zanini and collaborators ${ }^{30}$ in the northeast, showed a high consumption by adolescents of soft drinks, sweets and fried food per day; and $60 \%$ of the adolescents studied consumed at least one of the three items cited, and $10 \%$ consumed the three of them. In the overall analysis of the results it is noted high prevalence of children and adolescents followers of an inadequate life style, which can lead to the development of excess weight and its complications, if interventional measures are not taken.

The limitation of this study is the number of participants in the second step. Since many parents or responsible for the students did not attend the meeting days to receive explanations about the project and sign the informed consent form. These meetings occurred during the week and parents or guardians had difficulties to attend due to their work commitments. The analysis, therefore, was performed in schoolchildren who sought for the research team. It is possible that this group presents distinct results from the general population of children and adolescents. Despite of these limitations, the data of this step provided important subsidies for the development of educational activities in this population.

This is the first study to demonstrate the occurrence of nutritional transition in the city of Frei Paulo-Se, which is observed decrease in malnutrition and increased excess weight. When considering the lifestyle of children 
and adolescents, it became evident the predominance of sedentary habits, which summed to inadequate feeding practices favors the overweight occurrence in this population. The data indicate the need for further actions of the public sphere aimed to preventing and combating obesity, particularly with children and adolescents, aiming to present and future results.

\section{Contribution in public health}

The excess of weight in children and adolescents

is increasing and causing serious health problems as diabetes and cardiovascular diseases. Therefore, studies like this are important to alert the competent organs about this public health problem. Furthermore, the results of this study allowed the development of educational activities in collaboration with professionals of the Family Health Strategy and of schools. It is important to highlight that all participants with any problems caused by obesity was referred to treatment.

\section{REFERENCES}

1. Lopes PCS, Prado SRLA, Colombo P. Fatores de risco associados à obesidade e sobrepeso em crianças em idade escolar. Rev Bras Enferm . 2010; 63(1):73-8. DOI: http://dx.doi.org/10.1590/S0034-71672010000100012

2. World Health Organization (WHO). Obesity and overweight. WHO; 2015. [Cited 2016 jun 2]. Available in: http://www.who.int/mediacentre/factsheets/fs311/en/.

3. Vigitel Brasil. Vigilância de fatores de risco e proteção para doenças crônicas por inquerito telefônico. [Cited 2015 oct 8]. 2014. p. 37. Available in: http://www.abeso.org.br/uploads/ downloads/72/553a243c4b9f3.pdf.

4. Brasil. Ministério da Saúde. Pesquisa de Orçamentos Familiares 2010. [Cited 2016 jun 2]. Available in: http://www.abeso.org.br/uploads/downloads/70/553a23f27da68.pdf.

5. Pinhas-Hamiel O, Zeitler P. The global spread of type 2 diabetes mellitus in children and adolescents. J Pediatr. 2005;146(5):693-700. DOI: http://dx.doi.org/10.1016/j.jpeds.2004.12.042

6. Friedemann C, Heneghan C, Mahtani K, Thompson M, Perera R, Ward AM. Cardiovascular disease risk in healthy children and its association with body mass index: systematic review and meta-analysis. BMJ 2012;345:e4759. DOI: https://dx.doi.org/10.1136/bmj.e4759

7. Wearing SC, Hennig EM, Byrne NM, Steele JR, Hills AP. Musculoskeletal disorders associated with obesity: a biomechanical perspective. Obes Rev. 2006;7(3):239-50. DOI: https://dx.doi.org/10.1111/j.1467-789X.2006.00251.x

8. Damiani D. Obesidade na infância e adolescência: um extraordinário desafio! Arq Bras Endocrinol Metabol. 2000;44(5):363-5. DOI: http://dx.doi.org/10.1590/S0004-27302000000500002

9. Carvalho EAA, Simão MTJ, Fonseca MC, Andrade RG, Ferreira MSG, Silva AF, et al. Obesity: epidemiological aspects and prevention. Rev Medi Minas Gerais. 2013;23(1):72-80. DOI: https://dx.doi.org/10.5935/2238-3182.20130012

10. Williams J, Scarborough P, Townsend N, Matthews A, Burgoine T, Mumtaz L, et al. Associations between Food Outlets around Schools and BMI among primary students in england: A Cross-Classified MultiLevel Analysis. PLoS One. 2015;10(7):e0132930. DOI: https://dx.doi.org/10.1371/journal.pone.0132930

11. Onis M, Onyango AW, Borghi E, Siyam A, Nishida C, Siekmann J. Development of a WHO growth reference for school-aged children and adolescents. Bull World Health Organ. 2007; 85(9):660-7. DOI: https://dx.doi.org/10.1590/S0042-96862007000900010

12. Dias PJP, Domingos IP, Ferreira MG, Muraro AP, Sichieri R, Gonçalves-Silva RMV. Prevalência e fatores associados aos comportamentos sedentários em adolescentes. Rev Saude Publica. 2014;48(2):266-74. DOI: http://dx.doi.org/10.1590/S0034-8910.2014048004635

13. Canadian Paediatric Society. Impact of media use on children and youth. Paediatr Child Health. 2003;8(5):301-17.

14. Brasil. Ministério da Saúde. Caderno do gestor do PSE [page on the Internet]. 2015 [Cited 2016 jun 30]. p. 68. Available in: http://bvsms.saude.gov.br/bvs/publicacoes/caderno_gestor_pse.pdf.

15. Onis M, Onyango AW, Van den Broeck J, Chumlea WC, Martorell R. Measurement and standardization protocols for anthropometry used in the construction of a new international growth reference. Food Nutr Bull. 2004;25(1 Suppl):S27-36. DOI: https://dx.doi.org/10.1177/15648265040251S104

16. Ramires EKNM, Menezes RCE, Oliveira JS, Oliveira MAA, Temoteo TL, Longo-Silva G, et al. Nutritional status of children and adolescents from a town in the semiarid Northeastern Brazil. Rev Paul Pediatr. 2014;32(3):200-7. DOI: https://dx.doi.org/10.1590/0103-0582201432309

17. Leal VS, Lira PIC, Menezes RCE, Oliveira JS, Sequeira LAS, Andrade SLLS, et al. Fatores associados ao declínio do déficit estatural em crianças e adolescentes em Pernambuco. Rev Saude Publica. 2012;46(2):234-41. DOI: http://dx.doi.org/10.1590/S0034-89102012005000015 
18. Mazaro IAR, Zanolli ML, Antonio MARGM, Morcillo AM, Zambon MP. Obesidade e fatores de risco cardiovascular em estudantes de Sorocaba, SP. Rev Assoc Med Bras. 2011;57(6):674-80. DOI: http://dx.doi.org/10.1590/S0104-42302011000600015

19. Barreto Neto AC, Andrade MIS, Lima VLM, Diniz AS. Body weight and food consumption scores among adolescents in the northeast of Brazil. Rev Paul Pediatr. 2015;33(3):318-25. DOI: http://dx.doi.org/10.1016/j.rpped.2015.01.002

20. Kelly AS, Barlow SE, Rao G, Inge TH, Hayman LL, Steinberger J, et al. Severe obesity in children and adolescents: identification, associated health risks, and treatment approaches: a scientific statement from the American Heart Association. Circulation. 2013;128(15):1689-712. DOI: http://dx.doi.org/10.1161/CIR.0b013e3182a5cfb3

21. Cabrera TFC, Correia IFL, Santos DO, Pacagnelli FL, Prado MTA, Silva TD, et al. Análise da prevalência de sobrepeso e obesidade e do nível de atividade física em crianças e adolescentes de uma cidade do Sudoeste de São Paulo. J Hum Growth Dev. 2014;24(1):1-6. DOI: http://dx.doi.org/10.7322/jhgd.73455

22. Ng M, Fleming T, Robinson M, Thomson B, Graetz N, Margono C, et al. Global, regional, and national prevalence of overweight and obesity in children and adults during 1980-2013: a systematic analysis for the Global Burden of Disease Study 2013. Lancet. 2014;384(9945):766-81. DOI: http://dx.doi.org/10.1016/S0140-6736(14)60460-8

23. Polderman J, Gurgel RQ, Barreto-Filho JAS, Roelofs R, Ramos REDO, Munter JS, et al. Blood pressure and BMI in adolescents in Aracaju, Brazil. Public Health Nutr. 2011;14(6):1064-70. DOI: http://dx.doi.org/10.1017/S1368980010003666

24. Guilherme FR, Molena-Fernandes CA, Guilherme VR, Fávero MTM, Reis EJB, Rinaldi W. Physical inactivity and anthropometric measures in school children from Paranavaí, Paraná, Brazil. Rev Paul Pediatr. 2015;33(1):50-5. DOI: http://dx.doi.org/10.1016/j.rpped.2014.11.009

25. Aires L, Silva P, Silva G, Santos MP, Ribeiro JC, Mota J. Intensity of physical activity, cardiorespiratory fitness, and body mass index in youth. J Phys Act Health. 2010;7(1):54-9. DOI: https://dx.doi.org/10.1123/jpah.7.1.54

26. Lucena JMS, Cheng LA, Cavalcante TLM, da Silva VA, de Farias Júnior JC. Prevalência de tempo excessivo de tela e fatores associados em adolescentes. Rev Paul Pediatr. 2015;33(4):407-14. DOI: https://dx.doi.org/10.1016/j.rpped.2015.04.001

27. Prentice-Dunn H, Prentice-Dunn S. Physical activity, sedentary behavior, and childhood obesity: A review of cross-sectional studies. Psychol Health Med. 2012;17(3):255-73. DOI: https://dx.doi.org/10.1080/13548506.2011.608806

28. Silva DAS, Silva RJS. Associação entre prática de atividade física com consumo de frutas, verduras e legumes em adolescentes do Nordeste do Brasil. Rev Paul Pediatr. 2015;33(2):167-73. DOI: http://dx.doi.org/10.1016/j.rpped.2014.09.003

29. Triches RM, Giugliani ERJ. Obesidade, práticas alimentares e conhecimentos de nutrição em esolares. Rev Saude Publica. 2005;39(4):541-7. DOI: http://dx.doi.org/10.1590/S0034-89102005000400004

30. Zanini RV, Muniz LC, Schneider BC, Tassitano RM, Feitosa WMN, González-Chica DA. Consumo diário de refrigerantes, doces e frituras em adolescentes do Nordeste brasileiro. Cienc Saude Coletiva. 2013;18(12):3739-50. DOI: http://dx.doi.org/10.1590/S1413-81232013001200030 


\section{Resumo}

Introdução: O Brasil passa por uma transição nutricional, no qual observa-se diminuição da desnutrição e aumento do excesso de peso.

Objetivo: Avaliar os dados antropométricos e o estilo de vida de escolares entre 4 a 17 anos do interior do Nordeste brasileiro.

Método: Estudo longitudinal realizado em duas etapas. A primeira ocorreu durante ação do Programa Saúde na Escola e foram coletados os dados antropométricos de 975 escolares. Na segunda etapa foi aplicado questionário para avaliar estilo de vida e alimentação. Os participantes foram estratificados em "sem excesso de peso" e "com excesso de peso" para fins de análise. O nível de significância usado nos testes estatísticos foi de $5 \%$.

Resultados: Na primeira etapa, menos de $2,0 \%$ dos alunos apresentaram baixa estatura para a idade. A prevalência de excesso de peso e desnutrição foi de 22,15\% e 5,23\%, respectivamente. Dos 134 participantes da segunda etapa, $47,76 \%$ estavam sem excesso de peso e $52,24 \%$ com excesso de peso. Com relação ao estilo de vida, o grupo sem excesso de peso apresentou maior porcentagem de integrantes insuficientemente ativos $(p=0,017)$ e um menor consumo de verduras, legumes e saladas $(p=0,015)$.

Conclusão: Os resultados demonstraram baixo déficit de estatura na população estudada e o excesso de peso foi mais prevalente que a desnutrição. As crianças e adolescentes apresentaram hábitos sedentários que associados às práticas alimentares inadequadas favorecem a ocorrência do excesso de peso.

Palavras-chave: sobrepeso, obesidade, criança, adolescente, consumo alimentar, estilo de vida

- The authors (2017), this article is distributed under the terms of the Creative Commons Attribution 4.0 International License (http:// creativecommons.org/licenses/by/4.0/), which permits unrestricted use, distribution, and reproduction in any medium, provided you give appropriate credit to the original author(s) and the source, provide a link to the Creative Commons license, and indicate if changes were made. The Creative Commons Public Domain Dedication waiver (http://creativecommons.org/publicdomain/zero/ $1.0 /)$ applies to the data made available in this article, unless otherwise stated. 